\title{
Technological Adoption For The Online System of Public Aspirations and Complaints Service (Lapor) in Bandung City
}

\author{
Helga Meizhura $^{1 *}$, Dini Turipanam Alamanda ${ }^{2}$, and Fajar Sidiq Adi \\ Prabowo $^{3}$ \\ 1,2,3 Telkom University, Bandung, Indonesia
}

\begin{abstract}
The city government of Bandung has made serious efforts in solving the urban problems creatively through the utilization of ICT, known as Smart City. One of the smart government programs being implemented is the online public aspirations and complaints service through an application system called LAPOR. So far, the application is considered effective enough to engage public participation, eventhough there are also many contradictory and negative comments shared by the users. Therefore, it is important to find out the actual description of public acceptances for the LAPOR system.

The affecting factors of interest and behavior in using the system were identified by the model of UTAUT 2 developed by Venkatesh et al. In 2012. The data in this study was collected using questionnaires distributed to 405 respondents of those who live in Bandung city, either the users of LAPOR application or those who have not used it yet. The results showed that the most influential factor of interest in using the LAPOR system is Price Value. This indicates that public wants the proportional benefits of the costs incurred for using the system. Other influential factors are Hedonic Motivation, Social Influence, Habit, and Facilitating Condition. Hence, these findings will enable practitioners to gain information in improving the successful implementation of technology-based governance programs.
\end{abstract}

Keywords: Smart City, Smart Government, UTAUT 2

\section{INTRODUCTION}

The development of ICT (Information and Communication Technology) has brought significant impacts in human life, one of them is the internet. It is not only limited to Personal Computers (PC) and smartphone devices, but ICT has also entered various sectors, included the government. The development of technology and information in the governmenthas become a new innovation in urban areas to provide better services to the public, it is known as smart city. Among several smart cities in Indonesia, Bandung is the one which has made serious efforts in becoming a Smart City through the utilization of ICT to serve the community. In August 2016, Bandung was named the only city whose government has been using smart city contents wholly connected until the level of kelurahan (urban village). It is known as the smart government (Pikiran Rakyat, 2016).

Smart government is defined as the transformation of local government to be more transparent, efficient and open to their citizens through the use of ICT and

*Corresponding author. Email address: helgameizhura95@gmail.com 
the formulation of the smart city policies (Anthopoulos and Reddick, 2016). Bandung City Government has been very serious in making efforts to solvethe urban problems creatively through the utilization of ICT. One of the programs carried out is the system of Online Public Aspirations and Complaints Service (LAPOR). The system is a means of receiving aspirations and complaints from the citizens which are then managed and disposed to various related institutions to be responded directly. Though the application is considered to be quite effective in engaging public participation, this is in fact contrary to the user feedbacks on Google Play in which there are more negative comments than the positive ones concerning the LAPOR system.

To find out the actual description of public acceptance for the LAPOR system aiming to realize the efficiency, effectiveness, transparency, and accountability of governance, this research has adopted the modified UTAUT 2 thinking framework by Marhaeni and Indrawati which consists of seven indicators taken from the previous model of UTAUT: Performance Expectancy, Effort Expectancy, Social Influence, and Facillitating Condition, and three additional constructs: Hedonic Motivation, Price Value, and Habit (Venkatesh et al., 2012). By using this model, the factors of user considerations and behavioral tendencies in the utilization of the LAPOR system could be identified.

\section{LITERATURE STUDY AND HYPHOTESES DEVELOPMENT \\ 2.1 Literature Study \\ 2.1.1 Smart City}

The concept of smart city is defined as the icon of a habitable city with sustainable developments (Chourabi et al., 2012). While other notions say that smart city is a city which encourages sustainable economic growth by utilizing information to make better decisions, anticipate problems proactively, and coordinate resources to effectively operate (IBM, 2011). Smart city is categorized into six smart characteristics: Smart Economy, Smart People, Smart Government, Smart Mobility, Smart Environment, and Smart Living (Giffinger and Gudrun, 2010).

\subsubsection{Smart Government}

Many countries in the world have now also benefited from the emergence of ICTs which improve their urban governances. An ICTbased government is known as smart government which is broadly interpreted as the integration of technology, society, policies, practices, resources, social norms and information interacting to support the activities of the city government (Chourabi et al., 2012). Today, the concept of e-government has led to a higher level called smart government which leverages the power of "data" in the efforts to improve public services; To carry out integrated services; To engage with citizens; To work together in developing policies; And to implement solutions for the welfare of society (Harsh and Ichalkaranje, 2015). 


\subsubsection{Government 3.0}

Government 3.0 is known as a new paradigm in government activities to provide more customized public services and generate new jobs creatively. This is done by opening and sharing government data to public in order to encourage communications and collaborations between government departments and the society. Based on the Executive Summary of South Korea conducted by Open Government Partnership, government 3.0 aims to make government more serviceoriented, competent, and more transparent in order to achieve the happiness of every citizen (Cain, 2015).

\subsubsection{Open Government}

An open government generally means a broad-based and global movement to expand citizen access to the government works involving three core principles: Transparency: Civic Access, Participation: Civic Engagement, and Collaboration: Civic Involvement (Rogers and Lindsey, 2012). In practice, the term "open government" is often used to describe the initiative of placing government documents and information in cyberspace (the internet). Technological developments encourage open governance which facilitates people's access to information. Website development is considered to be important in the open government practices. It is not only limited in providing information but also enabling interactions between government and the citizens (Meijer et al., 2012).

\subsubsection{Unified Theory of Acceptance and Use of Technology (UTAUT) 2}

UTAUT 2 is the development of the previous UTAUT model formulated by Venkatesh et al. In 2003. UTAUT 2 is one of the best models to predict the acceptance of technology and explain the user's behavior in using the technology (Kumar, 2013). A research conducted by Venkatesh et al. In 2012 presented UTAUT 2 by adding extra key constructs and their relations to each other into the previous UTAUT model to be tailored to the context ofthe consumer use. The three other new constructs added are Hedonic Motivation, Price Value, and Habit, and the moderating variables used are Age, Gender, and Experience.

a) Performance Expectancy $\rightarrow$ Behavioral Intention

The definition ofPerformance Expectancy (PE) according to Venkatesh et al. (2003) is the extent to which individuals believe that the use of a system will help them to achieve the maximum performance in their works. Furthermore, it is explained that PE is the strongest predictor of Behavioral Intention (BI). While, according to Marhaeni and Indrawati (2015) BI is defined as the extent to which a person will use a particular technology in the future.

A research by Alkhunaizan and Love (2012) concerning the use of mobile commerce ( $m$-commerce) in Saudi Arabia discovered that $\mathrm{PE}$ provides the strongest influence on BI. It is in line with Oye et al's research (2011) regarding the acceptance and use of ICT by the academic staff at LASU University, Nigeria in which PE was found to be the most influencing factor of interest for technology use at the university. In addition, in terms of their relations 
moderated by Age and Gender, a research by Al-Gahtani et al. (2007)figured out that there are no significant interactions of Age and Gender on the influence of PE against BI.

b) Effort Expectancy $\rightarrow$ Behavioral Intention

According to Venkatesh et al. (2003), Effort Expectancy (EE) is the level of convenience perceived by the users in using a system. Based on a study by Oye et al. (2011), EE wasfound to be the most influential factor toward BI in the use of ICT by the academic staff at LASU University, Nigeria. Then, the same thing was also expressed by Pahnila et al. (2011) that EE was an important factor in the acceptance of Tao Bao, the Chinese eBay. Furthermore, the EE's influence on BI moderated by Gender and Age was more significant in older female employees (Venkatesh et al., 2003). However, a research by Yu (2012) found that none of the Age and Gender affect the influence of EE on BI.

c) Social Influence $\rightarrow$ Behavioral Intention

Social Influence (SI) is defined by Venkatesh et al. (2003) as the extent to which a person perceives the people in his or her social environment, friends and family, can influence his behavior to use a system. Furthermore,it was also explained that SI is the factor determining BI directly, the most significant influence takes place in older female employees. Another study by Lewis et al. (2013) also showed that SI has an influence on BI and its effect becomes more complex when the moderating variable of Gender is involved.

d) Facilitating Conditions $\rightarrow$ Behavioral Intention

The definition of Facilitating Conditions (FCs) is how much someone believes in factors such as the presence of devices, knowledge, guidance, and other people in the social groupcan support the use of a system (Venkatesh et al., 2003). Based on the results of research by Venkatesh et al. (2012) regarding the UTAUT 2 model, FCs were also found to have an influence on BI moderated by Gender and Age.

e) Hedonic Motivation $\rightarrow$ Behavioral Intention

Hedonic Motivation (HM) is defined by Venkatesh et al. (2012) as the sense of pleasure and comfort felt from the use of a technology, which plays an important role in determining the acceptance and use of technology. Further research by Venkatesh et al. (2012) then found that HM influenced BI and the influence was stronger in younger men who had little experience in usingthe technology. Another study conducted by Kumar (2013) mentioned the term "Perceived Enjoyment" which focuses on whether consumers use the service or technology for convenience or not. These studies revealed that Perceived Enjoyment had a positive influence on BI. While, Xu (2014) who conducted a research in the context of Social Network Games also found that the Perceived Enjoyment had a significant influence on BI. 
f) Price Value $\rightarrow$ Behavioral Intention

Venkatesh et al. (2012) defined Prive Value (PV) as the benefit perceived by users over the costs incurred for using a technology / system. A research conducted by Kumar (2013) used the term "Price Level", meaning the consumer attitudes toward a technology at a certain price level (will accept or reject), including whether the consumer is satisfied with the service of the certain price level and how much money the consumer expect to spend for the service. The result of Kumar's study (2013) found that Price Level had a negative influence on BI. Yet, another study by Alkhunaizan and Love (2012), using the term "Cost" to describe $\mathrm{PV}$, stated that Cost was significantly able to predict usage intention in the context of mobile commerce customers in Saudi Arabia.

g) Habit $\rightarrow$ Behavioral Intention

Habit is the extent to which someone automatically tends to use an information system which he or she has learned (Venkatesh et al., 2012). Based on the research, the additional variables of Facilitating Conditions, Hedonic Motivation, Price Value, and Habit as the predictors of BI could increase the value of BI's $\mathrm{R}^{2}$ which was originally only $70 \%$ becoming $74 \%$. Lewis et al., (2013) also suggested that Habit has a significant influence on BI.

h) Behavioral Intention $\rightarrow$ Use Behavior

Use Behavior (UB) is mentioned as a measure of the actual use frequency of a technology by the users (Wu et al., 2012). In the UTAUT 2 model, the effect on UB is also determined by the Habit factor, in which Venkatesh et al. (2012) found that older men with more experienced use of technology tended to be more accustomed to using technology. Furthermore, the research conducted by $\mathrm{Wu}$ et al.(2012) also revealed that BI has a positive influence on UB.

i) Facilitating Conditions $\rightarrow$ Use Behavior

Venkatesh et al. (2003) explained that the effect of FCs on the use of technology is stronger in older employees and it will be stronger and stronger as the experience increases. Another study conducted by Fillion et al. (2012) found that FC had a positive influence on the use of technology, but that effect was not moderated by Age, Gender, and Experience.

j) Habit $\rightarrow$ Use Behavior

Based on the research conducted by Venkatesh et al. (2012), the influence of Habit on UB is stronger in older men who have more experience. In addition, Pahnila et al. (2011) who conducted research on the use of Chinese eBay used another term "Actual Use" for UB and found that Habit hasa significant influence on the Actual Use.

\subsection{Hypotheses Development}

In this study, the compilation of the framework refers to the modified model of UTAUT 2 developed by Marhaeni and Indrawati as in Figure 2.1, with the explanation of the variables as follows: 
a) Independent variables (exogen): Performance Expectancy (PE), Effort Expectancy (EE), Social Influence (SI), Facilitating Conditions (FC), Hedonic Motivation (HM), Price Value (PV), and Habit $(\mathrm{H})$.

b) Dependent variable (endogen): Use Behavior (UB).

c) Intervening variable (second endogen): Behavioral Intention (BI).

d) Moderating variables: Age and Gender.

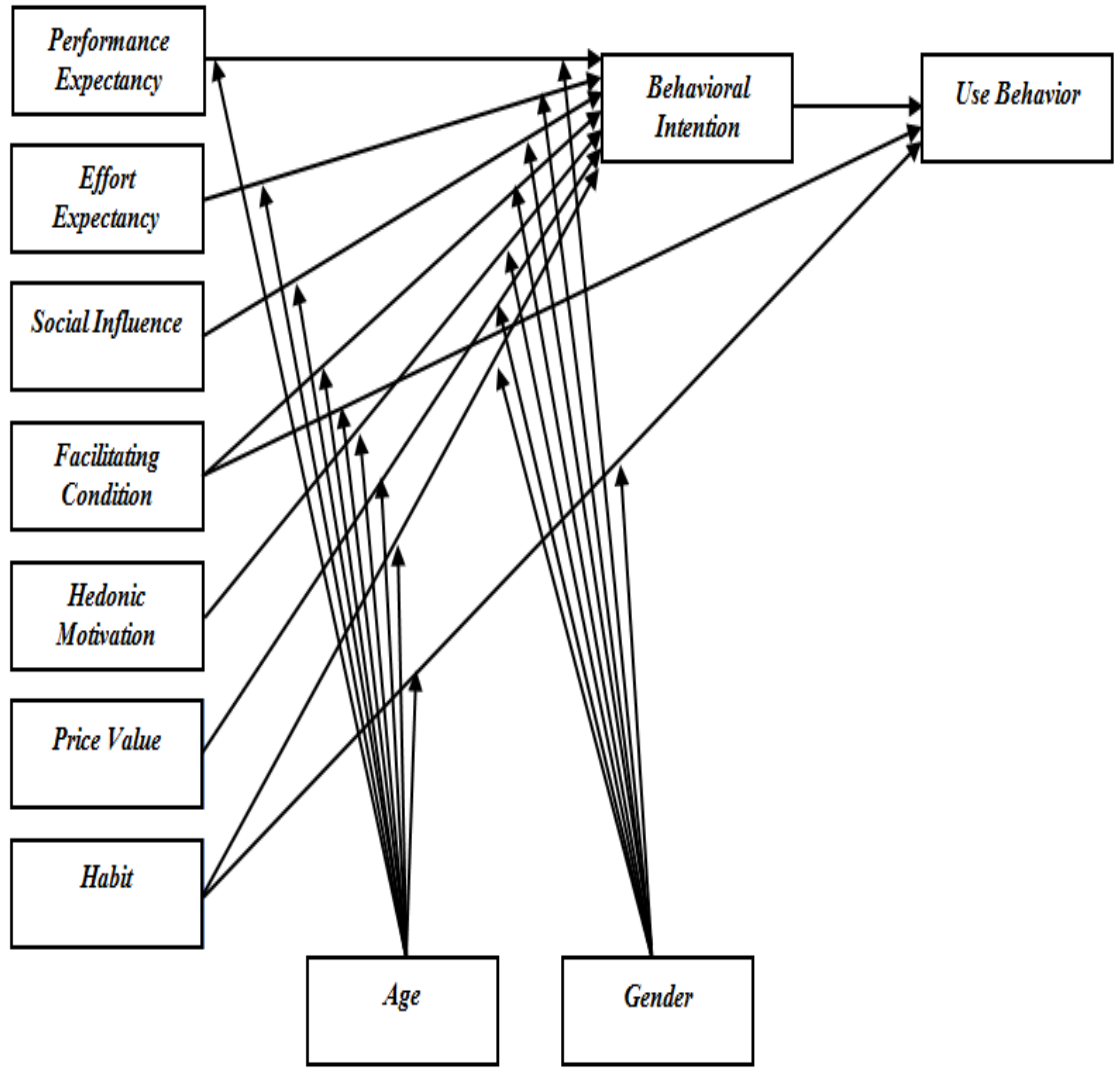

Figure 1 The Modified Thinking Framework of UTAUT 2

This study only usesAge and Gender as the moderating variables, it wasexplained that the two moderating variables could increase the $\mathrm{R}^{2}$ value ofBehavioral Intention and Use Behavior (Marhaeni and Indrawati, 2015). The study modified the previous UTAUT 2 model by Venkatesh, et al. By addingAge which moderated the relationship between Facilitating Conditions andUse Behavior. This is supported by the hypothesis test results from Marhaeni and Indrawati's research which found that Facilitating Conditions hada positive and significant impact on Use Behavior moderated by Age.

Furthermore, this study also eliminatedthe moderator variable of Experience since the data was only retrievedat a particular time. This opinion is supported by Venkatesh et al. who operated the variable of Experience into three levels of time: the post-training period, a lenght of time a system takes 
Technological Adoption For The Online System of Public Aspirations and Complaints Service (Lapor) in Bandung City

after it starts to be in use, ie one month; And three months. It means the variable of Experience requires a period of post-training for retrieving data. Hence, this study also eliminated the moderating variable of Experience from the UTAUT 2 model.

From the results of theoretical searches and previous studies, the hypotheses used in this research are as follows:

Table 1 Research Hypotheses

\begin{tabular}{|c|c|}
\hline H1 & Performance Expectancy has a positive and significant effect on Behavioral Intention. \\
\hline H1a & The effect of Performance Expectancy on Behavioral Intention is moderated by Age. \\
\hline H1b & The effect of Performance Expectancy on Behavioral Intention is moderated by Gender. \\
\hline $\mathbf{H 2}$ & Effort Expectancy has a positive and significant effect on Behavioral Intention. \\
\hline H2a & The effect of Effort Expectancy on Behavioral Intention is moderated by Age. \\
\hline H2b & The effect of Effort Expectancy on Behavioral Intention is moderated by Gender. \\
\hline $\mathbf{H 3}$ & Social Influence has a positive and significant effect on Behavioral Intention \\
\hline H3a & The effect of Social Influence on Behavioral Intention is moderated by Age. \\
\hline H3b & The effect of Social Influence on Behavioral Intention is moderated by Gender. \\
\hline H4 & Facilitating Conditions has a positive and significant effect on Behavioral Intention. \\
\hline H4a & The effect of Facilitating Conditions on Behavioral Intention is moderated by Age. \\
\hline H4b & The effect of Facilitating Conditions on Behavioral Intention is moderated by Gender. \\
\hline H5 & Hedonic Motivation has a positive and significant effect on Behavioral Intention. \\
\hline H5a & The effect of Hedonic Motivation on Behavioral Intention is moderated by Age. \\
\hline H5b & The effect of Hedonic Motivation on Behavioral Intention is moderated by Gender. \\
\hline H6 & Price Value has a positive and significant effect on Behavioral Intention. \\
\hline H6a & The effect of Price Value on Behavioral Intention is moderated by Age. \\
\hline H6b & The effect of Price Value on Behavioral Intention is moderated by Gender. \\
\hline $\mathbf{H 7}$ & Habit has a positive and significant effect on Behavioral Intention. \\
\hline H7a & The effect of Habit on Behavioral Intention is moderated by Age. \\
\hline H7b & The effect of Habit on Behavioral Intention is moderated by Gender. \\
\hline H8 & Facilitating Conditions has a positive and significant effect on Use Behavior. \\
\hline H8a & The effect of Facilitating Conditions on Use Behavior is moderated by Age. \\
\hline H9 & Habit has a positive and significant effect on Use Behavior. \\
\hline H9a & The effect of Habit on Use Behavior is moderated by Age. \\
\hline H9b & The effect of Habit on Use Behavior is moderated by Gender. \\
\hline H10 & Behavioral Intention has a positive and significant effect on Use Behavior. \\
\hline
\end{tabular}

\section{RESEARCH METHODOLOGY}

\subsection{Research Characteristics}

This research uses quantitative approach method, in which according to Sugiyono (2016: 7) that quantitative method is a scientific method because it has fulfilled the scientific norms which are concrete / empirical, objective, measurable, rational, and systematic. Based on its purpose, this research is classified into a descriptive research in which the reasearch is usually done 
when the researchers have already known the factors or variables to measure an object or field but not the relationship amongthe factors or variables.

Based on the type of investigation, this research belongs to causal research aiming to understand the variables of cause and effect. The characteristics of this study when viewed from the time of execution isa cross-sectional research type, as described by Sekaran (2006: 177) that a cross-sectional study is done using a one-timed data collection only, for example during the period of a day, a week, or a month to answer the research questions.

\subsection{Sampling Technique}

This research used non-probability sampling technique since the exact number of population related to the amount of LAPOR application usage was not known. In detail, this research used non-probability sampling technique with the purposive sampling type. According to Zikmund et al. (2010: 396), the purposive sampling is a non-probability sampling technique in which certain individuals are selected to be sampled based on the conformity of required characteristics. The characteristics set by the researchers for the samples were:

1) People who live in the city of Bandung.

2) The moderating variable of age was used and divided into two categories, namely young age and old age. According to the United Nations (UN), the category of young is represented by the ages of 1524 years, while the ages above 24 years are categorized old. Therefore, this study uses the ages of 15-24 for the young age category, while the ages above 24 years are categorized as old.

Since the population number in this study was unknown, then the determination of the sample number used the Bernoulli formula. In accordance with the sample size calculation using the formula, the minimum sample size used in this study was 385 respondents and the numbers were rounded from 384.16. This study used SEM analysis technique, in which according to Kline, the appropriate number of samples for the SEM calculations is more than 200 for more complex models (Latan, 2012: 45). Eventually, the researchers set the total samples to be used were 400 respondents of the people who lived in the city of Bandung, both the users of the LAPOR system andthose who have notused it yet.

\section{RESULTS}

This research used two main characteristics as the moderating variables, they were Age and Gender. Based on age, $67 \%$ of the respondents were dominated by people aged 15-24 years and 33\% of the ages over 24 years old. Based on gender, women were dominated by $57 \%$, and men as much as $43 \%$. While, for the test model, in the SEM-PLS method, it was divided into two stages namely Outer Model and Inner Model.

\subsection{Outer Model}

For the Outer Model, the validity and reliability tests were carried out against the indicators used in the study. The first stage done was the Indicator Reliability test in which the loading factor must be $>0.70$ to be considered valid. Based on 
Technological Adoption For The Online System of Public Aspirations and Complaints Service (Lapor) in Bandung City

the test results, all indicators of the questionnaire in this study werethereby stated valid. This could happen due to the overall loading factor of the indicatorswhich was bigger than 0.7 and these results were referred to the rule of thumb (Garson, 2016), as can be seen in Table 2.

Table 2 Results of Indicator Loading values

\begin{tabular}{ccccc}
\hline Construct & Item & $\begin{array}{c}\text { Indicator } \\
\text { Loading }\end{array}$ & $\begin{array}{c}\text { Rule of } \\
\text { Thumb }\end{array}$ & Conclusion \\
\hline \multirow{2}{*}{$\begin{array}{c}\text { Performance } \\
\text { Expectancy }\end{array}$} & PE1 & 0.875 & 0.7 & Valid \\
\cline { 2 - 5 } & PE2 & 0.906 & 0.7 & Valid \\
\cline { 2 - 5 } Effort Expectancy & PE3 & 0.879 & 0.7 & Valid \\
\cline { 2 - 5 } & EE1 & 0.894 & 0.7 & Valid \\
\cline { 2 - 5 } & EE2 & 0.900 & 0.7 & Valid \\
\hline \multirow{3}{*}{ Social Influence } & EE3 & 0.877 & 0.7 & Valid \\
\cline { 2 - 5 } & SI1 & 0.885 & 0.7 & Valid \\
\cline { 2 - 5 } Facilitating & SI2 & 0.884 & 0.7 & Valid \\
\cline { 2 - 5 } Conditions & SI3 & 0.837 & 0.7 & Valid \\
\cline { 2 - 5 } & FC2 & 0.901 & 0.7 & Valid \\
\cline { 2 - 5 } Hedonic & FC3 & 0.898 & 0.7 & Valid \\
\cline { 2 - 5 } Motivation & HM1 & 0.870 & 0.7 & Valid \\
\cline { 2 - 5 } & HM2 & 0.870 & 0.7 & Valid \\
\hline
\end{tabular}

The next stage conducted was the Internal Consistency Reliability test, it is usually usedas the reference to measure the overall reliability of the constructs. The criterion is that the value of the composite reliability must be $>0.70$ for a construct to be considered reliable (Hair et al., 2014). Since all variables in this research have the value of composite reliability bigger than 0.7 . Thus, the nine constructs / research variables can be said to be reliable. This can be seen in Table 3 below.

Table 3 Results of Composite Reliabilityvalues

\begin{tabular}{cccl}
\hline Construct & $\begin{array}{c}\text { Composite } \\
\text { Reliability }\end{array}$ & Rule of Thumb & Conclusion \\
\hline Performance Expectancy & 0.917 & 0.7 & Reliable \\
\hline Effort Expectancy & 0.920 & 0.7 & Reliable \\
\hline Social Influence & 0.903 & 0.7 & Reliable \\
\hline Facilitating Conditions & 0.919 & 0.7 & Reliable \\
\hline Hedonic Motivation & 0.887 & 0.7 & Reliable \\
\hline Price Value & 0.918 & 0.7 & Reliable \\
\hline Habit & 0.874 & 0.7 & Reliable \\
\hline Behavioral Intention & 0.935 & 0.7 & Reliable \\
\hline Use Behavior & 0.965 & 0.7 & Reliable \\
\hline
\end{tabular}

After measuring the reliability of the constructs and indicators performed, the next step taken was measuring the validity of the research model. So, then the test of Convergent Validity was done. This test requires that the AVE (Average Variance Extracted) value must be 0.5 or bigger, which means that a construct has 
a good ability explain the indicator. (Hair et al., 2014). According to the test results, the nine constructs in this study had the AVE value above 0.5 which means that the constructs have good abilities to explain the indicators. The results are shown in Table 4 below.

Table 4 Results of AVE value

\begin{tabular}{cccc}
\hline Construct & AVE & Rule of Thumb & Conclusion \\
\hline Performance Expectancy & 0.787 & 0.5 & Good \\
\hline Effort Expectancy & 0.793 & 0.5 & Good \\
\hline Social Influence & 0.756 & 0.5 & Good \\
\hline Facilitating Conditions & 0.792 & 0.5 & Good \\
\hline Hedonic Motivation & 0.723 & 0.5 & Good \\
\hline Price Value & 0.789 & 0.5 & Good \\
\hline Habit & 0.777 & 0.5 & Good \\
\hline Behavioral Intention & 0.827 & 0.5 & Good \\
\hline Use Behavior & 0.932 & 0.5 & Good
\end{tabular}

The last stage done in testing the Outer Model was the Discriminant Validity test. Hair et al. (2014) explained that this step requires the AVE square root value of each construct must be bigger than the AVE value of the construct to be declared valid. Based on the test results as in Table 5, it was found that allthe constructs in this study are valid because each of the $\sqrt{ }$ AVE value is bigger than the AVE values.

Table 5 Comparison Results of AVE and $\sqrt{ }$ AVE values

\begin{tabular}{cccc}
\hline Construct & AVE & $\sqrt{ } \boldsymbol{A} \boldsymbol{E}$ & Conclusion \\
\hline Performance Expectancy & 0.787 & 0.887 & Valid \\
\hline Effort Expectancy & 0.793 & 0.890 & Valid \\
\hline Social Influence & 0.756 & 0,869 & Valid \\
\hline Facilitating Conditions & 0,792 & 0.890 & Valid \\
\hline Hedonic Motivation & 0.723 & 0.850 & Valid \\
\hline Price Value & 0.789 & 0.888 & Valid \\
\hline Habit & 0.777 & 0.881 & Valid \\
\hline Behavioral Intention & 0.827 & 0.910 & Valid \\
\hline Use Behavior & 0.932 & 0.965 & Valid
\end{tabular}

The indicator loading value of each variable can also be seen in the model of calculation results with SmartPLS 3.0 as in Figure 2 which shows valid numbers for 25 indicators in this study. 
Technological Adoption For The Online System of Public Aspirations and Complaints Service (Lapor) in Bandung City

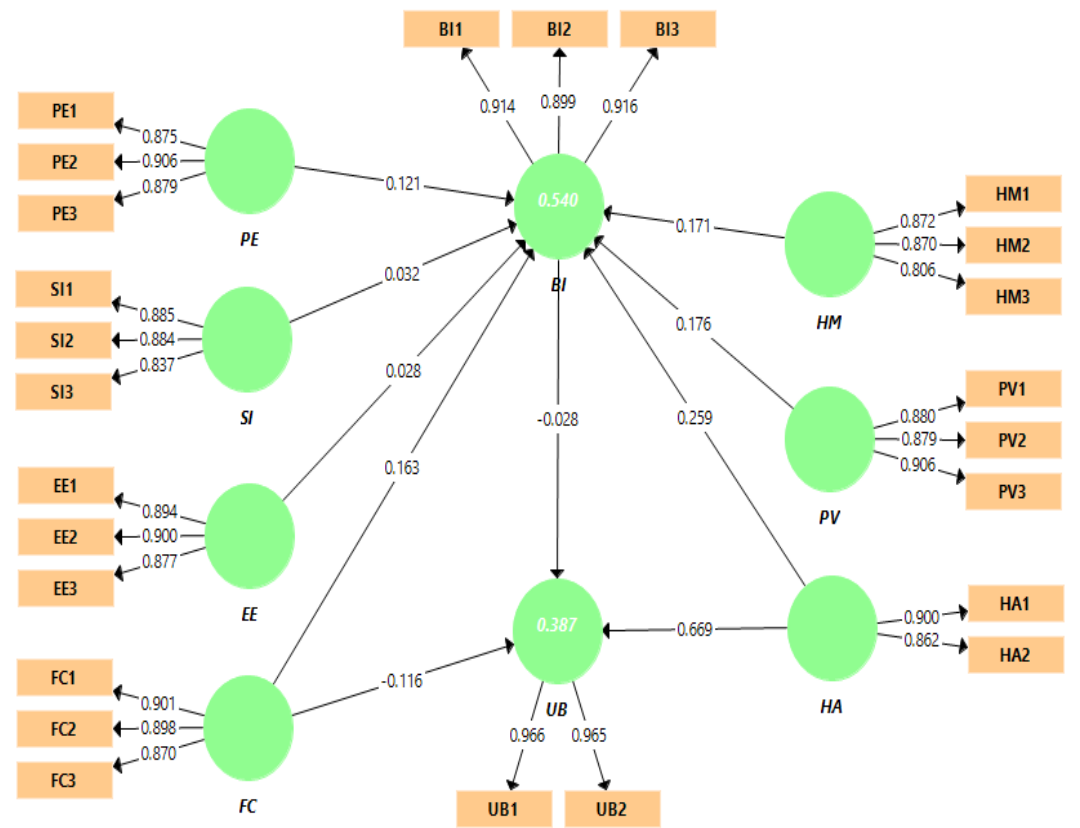

Figure 2 Output of the Outer Model using Smart PLS 3.0

\subsection{Inner Model}

In the inner model test of PLS, the criterion of adjusted $\mathrm{R}^{2}\left(\mathrm{R}^{2} \mathrm{adj}\right)$ was used. Hair et al. (2014) recommended the use of the $\mathrm{R}^{2}$ adj to avoid any bias. The following Table 6 describes the value of $\mathrm{R}^{2}$ and $\mathrm{R}^{2}$ adj of the endogenous latent constructs.

Table 6 The $\mathrm{R}^{2}$ and $\mathrm{R}^{2}$ adj values of endogenous Latent Constructs

\begin{tabular}{lcc}
\hline \multicolumn{1}{c}{ Construct } & Value of $\mathbf{R}^{\mathbf{2}}$ & Value of $\mathbf{R}^{\mathbf{2}}$ adj \\
\hline Behavioral Intention & 0.540 & 0.532 \\
\hline Use Behavior & 0.387 & 0.383 \\
\hline
\end{tabular}

The value of $\mathrm{R}^{2}$ adj in the Behavioral Intention construct is 0.532 , which means the Behavioral Intention is influenced by Performance Expectancy, Effort Expectancy, Social Influence, Facilitating Condition, Hedonic Motivation, Price Value, and Habit amounted to $53.2 \%$ while the rest $46.8 \%$ is influenced by other constructs Beyond this study. Furthermore, the Use Behavior construct is influenced by Behavioral Intention, Facilitating Condition, and Habit at $38.3 \%$ while $61.7 \%$ are influenced by other constructs outside of this study. Then the value of $\mathrm{R}^{2}$ in Table 6 will be calculated by the $\mathrm{Q}^{2}$ formula as follows:

$$
\begin{aligned}
\mathrm{Q} 2= & 1-(1-\mathrm{R} 12)(1-\mathrm{R} 22) \\
= & 1-(1-0.540)(1-0.387) \\
= & 1-(0.46)(0.613)
\end{aligned}
$$




$$
\begin{array}{ll}
= & 1-(0.28198) \\
= & 0.71802 \approx 0.718 \text { or } 71.8 \%
\end{array}
$$

In this study, the $\mathrm{Q}^{2}$ or predictive relevance score is 0.718 or $71.8 \%$. So, it can be concluded that the model can explain the data through Behavioral Intention and Use Behavior constructs influenced by other constructs at $71.8 \%$.

The next step wasthe hypotheses test with the criteria taken from the $t$ statistics or $t$-value of the research. In addition, the original sample number in the path coefficient is used to determine the positive or negative effects of latent constructs on the indicators and other constructs. These criteria are described as follows:

1) If the value of Path Coefficient is positive, then there is a positive influence between one construct and the others.

2) If the value of Path Coefficient is negative, then the influence direction of the constructs in this study is negative

3) If t count $>1.65$ (one-tailed), then $\mathrm{H}_{0}$ is rejected

4) If $\mathrm{t}$ count $\leq 1.65$ (one-tailed), then $\mathrm{H}_{0}$ is accepted

Table 7 Hypothesis Test Results

\begin{tabular}{cccccc}
\hline Hypothesis & Relationship & $\begin{array}{c}\text { Path } \\
\text { Coefficient }\end{array}$ & t count & t table & Conclusion \\
\hline H1 & PE -> BI & -0.028 & 0.468 & 1.650 & $\mathrm{H}_{0}$ accepted \\
\hline H2 & EE -> BI & -0.028 & 0.496 & 1.650 & $\mathrm{H}_{0}$ accepted \\
\hline H3 & SI -> BI & 0.163 & 3.012 & 1.650 & $\mathrm{H}_{0}$ rejected \\
\hline H4 & FC -> BI & 0.116 & 2.363 & 1.650 & $\mathrm{H}_{0}$ rejected \\
\hline H5 & HM -> BI & 0.259 & 4.814 & 1.650 & $\mathrm{H}_{0}$ rejected \\
\hline H6 & PV -> BI & 0.669 & 14.442 & 1.650 & $\mathrm{H}_{0}$ rejected \\
\hline H7 & HA -> BI & 0.171 & 2.694 & 1.650 & $\mathrm{H}_{0}$ rejected \\
\hline H8 & FC -> UB & 0.121 & 2.191 & 1.650 & $\mathrm{H}_{0}$ rejected \\
\hline H9 & HA -> UB & 0.176 & 2.955 & 1.650 & $\mathrm{H}_{0}$ rejected \\
\hline H10 & BI -> UB & -0.032 & 0.612 & 1.650 & $\mathrm{H}_{0}$ accepted \\
\hline
\end{tabular}

Based on Table 7, the results of $\mathrm{t}$ count on the hypotheses of $\mathrm{H} 1, \mathrm{H} 2$, and $\mathrm{H} 10$ show that $\mathrm{H}_{0}$ is accepted which means there is no significant influence of Performance Expectancy and Effort Expectancy variables on Behavioral Intention, and Behavioral Intention variable on Use Behavior. While the other hypotheses of $\mathrm{H} 3, \mathrm{H} 4, \mathrm{H} 5, \mathrm{H} 6, \mathrm{H} 7, \mathrm{H} 8$, and $\mathrm{H} 9$ show that $\mathrm{H}_{0}$ is rejected or $\mathrm{H}_{1}$ is accepted which means there are significant influences from the variables of Social Influence, Facilitating Condition, Hedonic Motivation, Price Value, and Habit on Behavioral Intention, As well as the variables of Facilitating Condition and Habit on Use Behavior.

This study uses two moderating variables namely Age and Gender. Both moderators were tested for their influences using multigroup analysis toward the relationship between the exogenous latent constructs and endogenous latent constructs by bootstrapping method. The test results can be seen in Table 8. related to Age moderator. 
Technological Adoption For The Online System of Public Aspirations and Complaints Service (Lapor) in Bandung City

Table 8 Results of Bootstrapping $t$ value intothe Moderating Variable of Age

\begin{tabular}{|c|c|c|c|c|}
\hline Hypothesis & Relation & $t$ count & t table & Conclusion \\
\hline $\mathrm{H} 3 \mathrm{a}$ & $\mathrm{SI}->\mathrm{BI}$ & 0.149 & 1.650 & $\mathrm{H}_{0}$ accepted \\
\hline $\mathrm{H} 4 \mathrm{a}$ & $\mathrm{FC} \rightarrow \mathrm{BI}$ & 1.348 & 1.650 & $\mathrm{H}_{0}$ accepted \\
\hline $\mathrm{H} 5 \mathrm{a}$ & $\mathrm{HM}->\mathrm{BI}$ & 0.467 & 1.650 & $\mathrm{H}_{0}$ accepted \\
\hline H6a & $\mathrm{PV}->\mathrm{BI}$ & 1.168 & 1.650 & $\mathrm{H}_{0}$ accepted \\
\hline $\mathrm{H7a}$ & $\mathrm{HA}->\mathrm{BI}$ & 0.259 & 1.650 & $\mathrm{H}_{0}$ accepted \\
\hline $\mathrm{H} 8 \mathrm{a}$ & FC -> UB & 1.451 & 1.650 & $\mathrm{H}_{0}$ accepted \\
\hline $\mathrm{H} 9 \mathrm{a}$ & $\mathrm{HA}->\mathrm{UB}$ & 0.179 & 1.650 & $\mathrm{H}_{0}$ accepted \\
\hline
\end{tabular}

In Table 9, the results of comparing $t$ count and t table show the numbers of t count are smaller than 1.65. Thus, all hypotheses tested; H1a, H3a, H4a, H5a, $\mathrm{H6a}, \mathrm{H} 7 \mathrm{a}, \mathrm{H} 8 \mathrm{a}$, and $\mathrm{H} 9 \mathrm{a}$ did not show any relationship of the variables moderated by Age.

Table 9 Results of Bootstrapping t value on the Moderating Variable of

\begin{tabular}{|c|c|c|c|c|}
\hline Hypothesis & Relation & $t$ count & t table & Conclusion \\
\hline $\mathrm{H} 3 \mathrm{~b}$ & SI $\rightarrow$ BI & 0.089 & 1.650 & $\mathrm{H}_{0}$ accepted \\
\hline $\mathrm{H} 4 \mathrm{~b}$ & FC $->$ BI & 1.386 & 1.650 & $\mathrm{H}_{0}$ accepted \\
\hline $\mathrm{H} 5 \mathrm{~b}$ & $\mathrm{HM}->\mathrm{BI}$ & 1.841 & 1.650 & $\mathrm{H}_{0}$ rejected \\
\hline $\mathrm{H} 6 \mathrm{~b}$ & $\mathrm{PV}->\mathrm{BI}$ & 0.678 & 1.650 & $\mathrm{H}_{0}$ accepted \\
\hline $\mathrm{H} 7 \mathrm{~b}$ & $\mathrm{HA}->\mathrm{BI}$ & 0.066 & 1.650 & $\mathrm{H}_{0}$ accepted \\
\hline $\mathrm{H} 9 \mathrm{~b}$ & HA -> UB & 0.260 & 1.650 & $\mathrm{H}_{0}$ accepted \\
\hline
\end{tabular}

Table 9 describes the results of bootstrapping t count intothe moderating variable of Gender. In hypothesis $\mathrm{H} 5 \mathrm{~b}$, it can be seen that the value of t count is 1.841 in which the number is bigger than $\mathrm{t}$ table. So, it can be concluded that the influence between Hedonic Motivation toward Behavioral Intention is moderated by Gender. Meanwhile, the hypotheses of H3b, H4b, H6b, H7b, and H9b show that the values of $t$ count are smaller than $t$ table, this means the variable relationships in the hypotheses are not moderated by Gender.

\section{DISCUSSION}

This study examined nine variables consisting of Performance Expectancy $(P E)$, Effort Expectancy (EE), Social Influence (SI), Facilitating Conditions (FCs), Hedonic Motivation (HM), Price Value (PV), Habit (H), Behavioral Intention (BI), and Use Behavior $(U B)$. The variables were tested using 25 items of questionnaire questions. The tests of the variables refer to $t$ statistics or $\mathrm{t}$ count and path coefficient of the relationsamong the variables to see the level of significance, and the positive and negative influences.

The result of the research on $\mathrm{H} 1$ shows the path coefficient value of -0.028 and the value of $\mathrm{t}$ count is not significant at 0.468 . This explains that $\mathrm{H} 0$ is accepted, which means Performance Expectancy has no positive and significant effect on Behavioral Intention in the use of LAPOR system in Bandung City. It can be interpreted that the extent to which a person believes that the use of the LAPOR 
system can assist him or her in delivering complaints and aspirations has not affected their intentions and motivations in using the system. This result is not in line with the previous research by Marhaeni and Indrawati (2015) stating that there is a significant influence between the two variables.

In $\mathrm{H} 2$, the relationship between Effort Expectancy and Behavioral Intentionis also not positive and significant sincethe path coefficient value is -0.028 and the $t$ count value is not significant at 0.496 . This means that the level of convenience expected by the respondents has not been able to influence their interest or motivation in using the LAPOR system. This result is in accordance with the research by Taiwo and Downe (2013), stated that the users of information systems are concerned about the ease of information system utilization. The complex system of apps / webs which are difficult to navigate can make a person less interested in adopting the app system or website.

$\mathrm{H} 3$ describes the positive and significant influential relationship between Social Influence and Behavioral Intention. Itis supported by the positive path coefficient value of 0.163 and t count value at 3.012. This can be interpreted that the people in the social environments of the respondents influence to their intentions to use the LAPOR system. Besides, This result is also supported by the research conducted by Marhaeni and Indrawati (2015), which explained that the people around the usersof a system not only determine their interest to using it at that moment, but will also influence their interest in continuing to use it in the future.

The calculation result for $\mathrm{H} 4$ shows the positive path coefficient value at 0.116 and significant $t$ count value at 2.363. The figures state that Facilitating Conditions have a positive and significant effect on Behavioral Intention. This can be interpreted as the availability of tools, knowledge, guidance, and other people around to support the use of the LAPOR system affects someone's intention to use the system. This statement goes along with the research conducted by Marhaeni and Indrawati (2015) on instant messaging applications, in which it was explained that the better the conditions that facilitate the use of a system, the higher the interest of a person to use the system / application.

It was explained in $\mathrm{H} 5$ that there is a positive and significant relationship between Hedonic Motivation and Behavioral Intention. It is indicated by the positive value of the path coefficient at 0.259 and the significant $t$ count value at 4.814. This means that the enjoyment and convenience perceived in using the LAPOR system may affect a person's interest and motivation in adopting the system. This is supported by the research conducted by Putra and Ariyanti (2013) stating that Hedonic Motivation shows the highest influence over other variables. Another study conducted by Marhaeni and Indrawati (2015) also explained that the higher the comfort obtained from the use of a system, the higher the interest of someone to use it.

H6 in this study states the relationship between Price Value and Behavioral Intention, in which the value of the path coefficient is positive at 0.669 and the $t$ count value is significant at 14.442 . The values show a positive and significant relationship between both variables. It can be interpreted that people's perceptions of the benefit over the financial costs incurred to use the LAPOR system may influence their intentions to use the system. The above statement is supported by the previous research conducted by Marhaeni and Indrawati (2015), stated that the greater the benefits derived from the use of a system, the greater the interest of a 
person to use the system. Further research by Putra and Ariyanti (2013) also explained that Price Value is one of the normal assessment of each individual against various types of decisions.

The calculation result of $\mathrm{H} 7$ shows significant $\mathrm{t}$ count value at 2,694 and positive path coefficient value at 0,171 . This means that Habitpositively and significantly influences Behavioral Intention in the use of LAPOR system in Bandung. The statement can be interpreted that the degree to which a person tends to use the system is automatically based on learning so that it affects his or her interest in using a technology. The result of the previous research by Marhaeni and Indrawati (2015) explained that the more someone uses a technology, the stronger the Habit will become. The growing Habit will also strengthen the interest of someone to use the system.

H8 in this study stated that Facilitating Conditions have a positive and significant impact on Use Behavior. It is proven by thesignificant t count value of 2,191 and the positive path coefficient value of 0,121 . This means that the presence of tools, knowledge, guidance, and other people of the social groups to support the use of the LAPOR system not only affects a person's interest, but also influences his or her usage behavior. This result is supported by the research conducted by Marhaeni and Indrawati (2015) regarding the use of instant messaging applications which explain that the compatibility of a system with its devices determines whether the user will be willing to use or just reject it.

H9 test shows significant t value at 2,955 and positive path coefficient value at 0,176 . These values indicate that Habit has a positive and significant effect on Use Behavior. It means, the habit factor is not only able to influence the interest in using LAPOR system, but may also influence the behavior in using the system. This is in line with the research by Marhaeni and Indrawati (2015) stating that the use of multiple technologies at once in a person's daily life can improve his or her habit in using the technology. Venkatesh et al. (2012) also explained that in the case of a multifunctional system, the users can select several different applications and use them in different ways so that they will tend to have a higher Habit.

H10 describes the relationship between Behavioral Intention and Use Behavior on the LAPOR system. The test shows the value of path coefficient is 0.032 and the $t$ count value is not significant at 0.612 . These results can be interpreted that the relationship of both does not have any positive and significant effect. It means that the intention of a person in using a system has not been able to influence his or her habit to continue usingthe system. This also goes along with the research conducted by Taiwo and Downe (2013), in which they also found that the influence between Behavioral Intention on Use Behavior was not significant.

In the moderatingvariable test of Age category, there is no correlation between the variables moderated by that category. While for the moderator of Gender, it appears that the moderator influences the relationship between Hedonic Motivation towards Behavioral Intention. This is in line with the research conducted by Marhaeni and Indrawati (2015) also the study by Putra and Ariyanti (2013). Based on the results of Marhaeni and Indrawati's research (2015), men tend to have higher attention to the factors of pleasure and comfort in using technology. 


\section{CONCLUSION AND RECOMMENDATION}

\subsection{Conclusion}

Based on the results of the research, it can be concluded that Price Value, Hedonic Motivation, Social Influence, Habit, and Facilitating Conditions have positive and significant impact on Behavioral Intention. The moderator of Gender moderates the relationship between Hedonic Motivation and Behavioral Intention positively and significantly, whereas Age is not found to moderate the relationships among other variables. Furthermore, the variables affecting Use Behavior positively and significantly are Habit and Facilitating Conditions, but there is no influence found among the variables moderated by Age or Gender.

\subsection{Recommendation}

In accordance with the conclusion, there are some suggestions to be given; firstly, the city government of Bandung should optimize the factors which influence the utilization of the existing resources and opportunities, so that the government can improve the implementation of the LAPOR program to be better. Secondly, for further research, the composition of respondents in each category is suggested to be more proportional so that the results will be more representative and describe the real situation. In addition, the future research may also include the moderating variable of Experience which is not examined in predicting the adoption and use of the LAPOR system on this study. In order to know the impact of the Experience moderator, a periodical data collection in a certain lenght of time can be done for more complex analysis and better result.

\section{References}

Al-Gahtani, S. S., Hubona, G. S., \& Wang, J. (2007). Information Technology (IT) in Saudi Arabia: Culture and the Acceptance and Use of IT. Information \& Management 44, 681-691.

Alkhunaizan, A. M., \& Love, S. (2012). What Drives Mobile Commerce? An Empirical Evaluation of The Revised UTAUT Model. International Journal of Management and Marketing Academy.

Anthopoulos, L., \& Reddick, C. G. (2016). Smart City and Smart Government: Synonymous or Complementary? Proceedings of the 25th International Conference Companion on World Wide Web (pp. 351-355). International World Wide Web Conferences Steering Committee.

Cain, G. (2015). Independent Reporting Mechanism (IRM): South Korea Progress Report 2014-2015. Open Government Partnership.

Chourabi, H., Nam, T., Walker, S., Gil-Garcia, J. R., Mellouli, S., Nahon, K., et al. (2012). Understanding Smart Cities: An Integrative Framework. 45th Hawaii International Conference on System Sciences (pp. 2289-2297). IEEE.

Fillion, G., Braham, H., \& Ekionea, J.-P. B. (2012). Testing UTAUT on The Use of ERP Systems by Middle Managers and End Users of Medium-to-Large- 
Technological Adoption For The Online System of Public Aspirations and Complaints Service (Lapor) in Bandung City

Sized Canadian Enterprises. Academy of Information and Management Sciences Journal.

Garson, G. D. (2016). Partial Least Squares: Regression \& Structural Equation Models. Asheboro, North Carolina: Statistical Associates Publishing.

Giffinger, R., \& Gudrun, H. (2010). Smart Cities Ranking: An Effective Instrument for the Positioning of Cities? Journal of the Centre of Land Policy and Valuations, 7-25.

Hair, J. F., Hult, G. T., Ringle, C. M., \& Sarstedt, M. (2014). A Primer on Partial Least Squares Structural Equation Modeling (PLS-SEM). California: SAGE Publications, Inc.

Harsh, A., \& Ichalkaranje, N. (2015). Transforming e-Government to Smart Government: A South Australian Perspective. Advances in Intelligent Systems and Computing, 9-16.

IBM. (2011). Creating Smarter Cities 2011 Storylines: IBM and Smart Cities. IBM Corporation.

Kumar, S. (2013). The Moderating Factors of 3G User Acceptance Technology in Shimla (India) Using UTAUT Model. International Journal of Computer Science \& Engineering Technology (IJCSET), 670-674.

Latan, H. (2012). Structural Equation Modeling: Konsep dan Aplikasi Menggunakan Program LISREL 8.80. Bandung: Alfabeta.

Lewis, C. C., Fretwell, C. E., Ryan, J., \& Parham, J. B. (2013). Faculty Use of Established and Emerging Technologies in Higher Education: A Unified Theory of Acceptance and Use of Technology Perspective. International Journal of Higher Education.

Marhaeni, G. A., \& Indrawati. (2015). Measurement for Analyzing Instant Messenger Application Adoption Using a Unified Theory of Acceptance and Use of Technology 2. International Business Management: Medwell Journals, 391-396.

Meijer, A. J., Deirdre , C., \& Hillebrandt, M. (2012). Open Government: Connecting Vision and Voice. Netherlands: International Review of Administrative Sciences - SAGE.

Oye, N., Iahad, N., \& Rabin, Z. A. (2011). A Model of ICT Acceptance and Use for Teachers in Higher Education Institutions. International Journal of Computer Science \& Communication Network.

Pahnila, S., Siponen, M., \& Zheng, X. (2011). Integrating Habit into UTAUT: The Chinese eBay Case. Pacific Asia Journal of the Association for Information Systems, Vol. 3 No. 2, 1-30.

Pikiran Rakyat. (2016, Agustus 17). Pemkot Bandung Raih Penghargaan Smart City Nusantara. Retrieved Februari 1, 2017, from Pikiran Rakyat: 
http://www.pikiran-rakyat.com/foto/2016/08/17/pemkot-bandung-raihpenghargaan-smart-city-nusantara-377568

Putra, G., \& Ariyanti, M. (2013). Pengaruh Faktor-Faktor dalam Modified Unified Theory of Acceptance and Use of Technology 2 (UTAUT 2) terhadap Niat Prospective Users untuk Mengadopsi Home Digital Service PT Telkom di Surabaya. Jurnal Manajemen Indonesia Vol. 12 - No. 4, 59-76.

Rogers, P., \& Lindsey, T. D. (2012). Principles of Open Government: Transparency, Participation \& Collaboration. California: California Research Bureau.

Sekaran, U. (2006). Research Methods for Business - Book 1, 4th Edition. Jakarta: Salemba Empat.

Sugiyono. (2016). Metode Penelitian: Kuantitatif, Kualitatif, dan R\&D. Bandung: Penerbit Alfabeta.

Taiwo, A. A., \& Downe, A. G. (2013). The Theory of User Acceptance and Use of Technology (UTAUT): A Meta-Analytic Review of Empirical Findings. Journal of Theoretical and Applied Information Technology Vol. 49 No.1, 4858.

Venkatesh, V., Morris, M. G., Davis, G. B., \& Davis, F. D. (2003). User Acceptance of Information Technology: Toward a Unified View. MIS Quarterly, Vol. 27, No. 3, 425-478.

Venkatesh, V., Thong, J. Y., \& Xu, X. (2012). Consumer Acceptance and Use of Information Technology: Extending The Unified Theory of Acceptance and Use of Technology. MIS Quarterly Vol. 36 No. 1, 157-178.

Wu, M.-Y., Yu, P.-Y., \& Weng, Y.-C. (2012). A Study on User Behavior for I Pass by UTAUT: Using Taiwan's MRT as an Example. Asia Pacific Management Review 17(1), 91-111.

$\mathrm{Xu}, \mathrm{X}$. (2014). Understanding User's Continued Use of Online Games: An Application of UTAUT 2 in Social Network Games. MMEDIA 2014: The Sixth International Conferences of Advances in Multimedia.

Yu, C.-S. (2012). Factors Affecting Individuals to Adopt Mobile Banking: Empirical Evidence from the UTAUT Model. Journal of Electronic Commerce Research, Vol 13 No 2, 104-121.

Zikmund, W. G., Babin, B. J., Carr, J. C., \& Griffin, M. (2010). Business Research Methods 8th Edition. Canada: South-Western CENGAGE Learning. 